\section{Erna Roostin ${ }^{1}$}

\title{
Penggunaan Media Geometri untuk Meningkatkan Kreativitas Anak dalam Menciptakan Bentuk
}

\begin{abstract}
Abstrak
\end{abstract}
Penelitian ini bertujuan untuk mengetahui dan mendapatkan gambaran mengenai peningkatan kreativitas anak dalam menciptakan bentuk di kelompok belajar Bina Insan Mandiri Kecamatan Cimalaka Kabupaten Sumedang tahun pelajaran 2017/2018 dalam kegiatan bermain bentuk-bentuk geometri. Metode yang digunakan adalah Penelitian Tindakan Kelas (PTK), teknik pengumpulan data yang dilakukan adalah Observasi dan Unjuk Kerja. Analisis data menggunakan deskriptif kualitatif. Hasil penelitian menunjukan bahwa dalam penggunaan media geometri untuk meningkatkan kreativitas anak dalam menciptakan bentuk dalam keterperincian dengan dukungan aspek keceriaan, kreatif, disiplin, antusias, dan mandiri. Peningkatan perilaku anak dalam aspek kreatif berkatagori baik pada data awal 27\%, siklus I 47\%, siklus II $67 \%$, dan siklus III 87\% dengan grafik meningkat. Peningkatan kreativitas anak dalam menciptakan 2 macam bentuk geometri menjadi bentuk yang baru pada katagori anak berkembang sangat baik dengan grafik meningkat terlihat pada data awal sebesar $40 \%$, siklus I sebesar 53\%, pada siklus II sebesar 73\%, dan terus meningkat pada siklus III sebesar $93 \%$.

Kata kunci: kreativitas, media geometri.

\begin{abstract}
This study aims to find out and get an idea of increasing children's creativity in creating forms in the Bina Insan Mandiri study group in Cimalaka District, Sumedang District in the year 2017/2018 in playing geometric shapes. The method used is Classroom Action Research (CAR), the data collection techniques carried out are Observation and Performance. Data analysis using qualitative descriptive. The results showed that the use of geometric media to improve children's creativity in creating forms in detail with the support of aspects of cheerfulness, creativity, discipline, enthusiasm, and independence. Improved children's behavior in the creative aspect is categorized well in the initial data $27 \%$, cycle I $47 \%$, cycle II $67 \%$, and cycle III $87 \%$ with graphs increasing. Increasing the creativity of children in creating 2 kinds of geometric shapes into a new form in the category of children developing very well with a graph increases seen in the initial data by $40 \%$, the first cycle of $53 \%$, in the second cycle of $73 \%$, and continues to increase in the third cycle of $93 \%$.
\end{abstract}

Keyword : creativity, geometric media

\footnotetext{
${ }^{1}$ Prodi PG-PAUD, STKIP Sebelas April Sumedang, Jln Angkrek Situ No.19 Sumedang e-mail : ernaroostin@ymail.com
}

Aulad : Journal on Early Childhood, 2019, 2(1), 1 - 8 


\section{PENDAHULUAN}

Pendidikan mengemban tugas untuk dapat mengembangkan potensi kreatif yang dimiliki setiap anak. Mereka perlu mendapat bimbingan yang tepat, sehingga memungkinkan mereka dapat mengembangkan potensi dan kemampuan secara optimal. Pada akhirnya kemampuan tersebut dapat berguna bagi dirinya, keluarga, bangsa dan negara.

Undang-Undang No. 20 tahun 2003 tentang Sistem Pendidikan Nasional Bab 1 Pasal 1 Ayat 14 yang menyatakan bahwa, Pendidikan Anak Usia Dini adalah suatu upaya pembinaan yang ditujukan kepada anak, sejak lahir sampai dengan usia enam tahun, yang dilakukan melalui pemberian rangsangan untuk membantu pertumbuhan dan perkembangan jasmani dan rohani agar anak memiliki kesiapan dan pendidikan lebih lanjut.

Kreativitas merupakan bakat yang secara potensial dimiliki setiap orang, dapat diidentifikasi dan dipupuk melalui pendidikan yang tepat, diantaranya pada Kober sebagai salah satu tempat diselenggarakannya Pendidikan Anak Usia Dini. Kreativitas salah satu potensi yang dimiliki setiap individu, penting untuk dikembangkan sejak usia dini karena dalam masa ini individu memiliki peluang yang sangat besar untuk dapat mengembangkan potensi tersebut.

Berdasarkan pengamatan sehari-hari, anak-anak Kober Bina Insan Mandiri Kecamatan Cimalaka Kabupaten Sumedang tahun pelajaran 2017/2018, dalam kreativitas menciptakan bentuk belum terlihat secara optimal, hal tersebut nampak seperti saat menyelesaikan pekerjaan, anak belum memiliki keberanian dalam hal bereksplorasi dan berekspresi, anak ragu, takut, dan kurang percaya diri, lebih sering meniru cara guru atau teman yang lain, anak masih tergantung pada contoh yang diberikan guru atau anak masih meniru cara guru menyelesaikan masalahnya.

Sama halnya seperti yang dikemukakan Sriningsih (2008 : 97) yang menyatakan bahwa, "Permainan mencipta dari bentuk geometri dapat menstimulasi perkembangan kreativitas dan imajinasi anak".

Melalui bermain kotak warna-warni berbagai bentuk, anak akan belajar mengenai bentuk-bentuk yang saling cocok dan tidak cocok, mengenai struktur yang mantap dan tidak mantap, mengenai keseimbangan. Selain itu pada saat bermain ragam bentuk geometri, fantasi atau imajinasi yang dimiliki anak dapat berkembang. Anak akan refleks menyampaikan hasil pemikirannya, baik dengan bentuk bahasa, motorik atau fisik, hasil kerja atau ciptaannya, sosial seperti bekerjasama dalam kelompok, emosional saat membagi dan menghargai hasil kerja, menemukan penyelesaian atas masalah yang dihadapinya, mendorong berfikir dengan logika, pemahaman mengenai konsep-konsep ruang (seperti di atas, samping, bawah, tinggi, rendah, lebar, sempit, besar, kecil), pengetahuan dan kemampuan matematik, serta seni (Sudono, 1995 : 5). Oleh karena itu salah satu kegiatan pembelajaran dengan bermain ragam bentuk geometri di Kolompok Bermain (Kober).

Penulis tertarik untuk melakukan penelitian dengan memanfaatkan bermacam bentuk geometri yang terbuat dari kayu (balok), kertas warna-warni, kertas kalender dan majalah yang sudah tidak terpakai. Melihat permasalahan diatas, maka penulis mengambil judul " Penggunaan media geometri untuk meningkatkan kreativitas anak dalam menciptakan bentuk ." (Penelitian Tindakan Kelas pada Kober Bina Insan Mandiri Desa Licin Kecamatan Cimalaka Kabupaten Sumedang Tahun Pelajaran 2017/2018).

\section{METODE PENELITIAN}

Aulad : Journal on Early Childhood, 2019, 2(1), $1-8$ 
Tujuan utama PTK adalah untuk memecahkan permasalahan nyata yang terjadi di dalam kelas sekaligus mencari jawaban ilmiah mengapa hal tersebut dapat dipecahkan melalui tindakan yang akan dilakukan. Tujuan khusus PTK adalah untuk mengatasi berbagai persoalan nyata guna memperbaiki atau meningkatkan kualitas proses pembelajaran di kelas. PTK bukan hanya bertujuan mengungkapkan penyebab dari berbagai permasalahan pembelajaran yang dihadapi seperti kesulitan siswa dalam mempelajari pokok-pokok bahasan tertentu, tetapi yang lebih penting lagi adalah memberikan pemecahan masalah berupa tindakan tertentu untuk meningkatkan kualitas proses dan hasil belajar. Hasil refleksi siklus pertama akan mengilhami dasar pelaksanaan siklus kedua.Setelah permasalahan ditetapkan, pelaksanaan PTK dimulai dengan siklus pertama yang terdiri atas empat tahap kegiatan. Hasil refleksi siklus pertama akan dapat diketahui keberhasilan atau hambatan dalam hasil tindakkan, peneliti kemudian mengidentifikasi permasalahannya untuk menentukan rancangan siklus berikutnya.

Rancangan yang digunakan dalam penelitian ini adalah Penelitian Tindakan Kelas (PTK) dilaksanakan melalui proses pengkajian berdaur atau siklus. Prosedur PTK ini diawali dengan melaksanakan observasi awal untuk melihat kondisi objektif pembelajaran khususnya dalam kreativitas anak dalam menciptakan bentuk. Kemudian melaksanakan tindakan melalui beberapa siklus sampai mencapai tujuan yang diharapkan.Untuk jelasnya prosedur penelitian tergambar sebagai berikut :

\section{Siklus Tindakan Kelas}

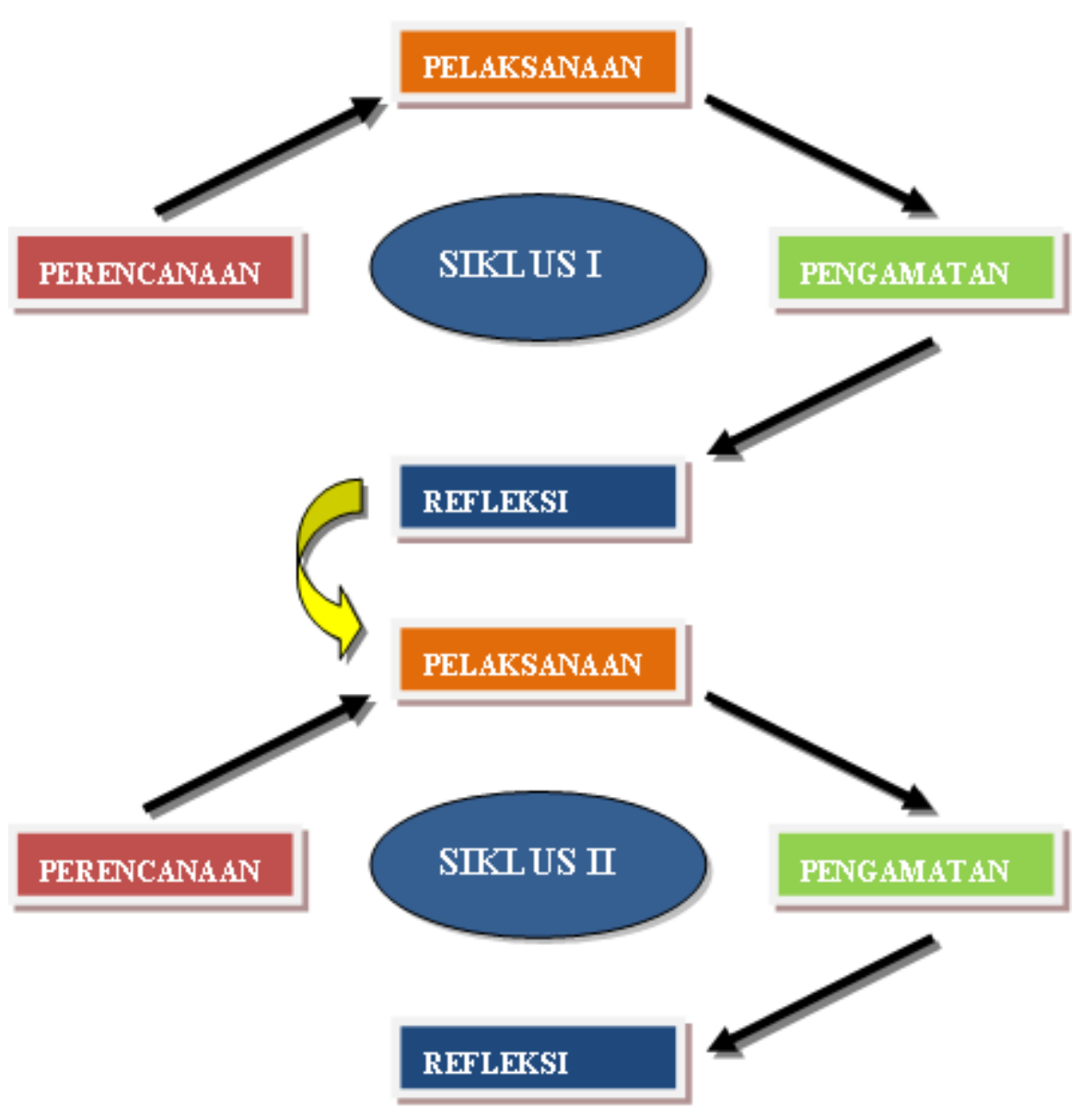

(adaptasi dari Kemmis dan Taggart dalam Wiriaatmadja, 2009:66)

Aulad : Journal on Early Childhood, 2019, 2(1), 1 - 8 
Teknik pengumpulan data merupakan langkah yang paling strategis dalam penelitian, karena tujuan utama dari penelitian adalah mendapatkan data. Oleh karena itu data yang diperoleh dalam penelitian ini bersumber dari:

1. Tes Observasi merupakan pengamatan langsung dengan menggunaan seluruh alat indera yang berfungsi.Selain itu tes observasi merupakan kegiatan pengambilan data untuk mengukur seberapa jauh pengaruh tindakan yang telah mencapai sasaran. Melalui penggunaan media geometri, peneliti dapat melihat secara langsung peningkatan kreativitas anak dalam menciptakan bentuk di Kober Bina Insan Mandiri Kecamatan Cimalaka Kabupaten Sumedang tahun pelajaran 2017/2018.

2. Tes perbuatan (unjuk kerja), adalah penilaian yang menuntut anak didik untuk melakukan tugas dalam perbuatan yang dapat diamati.

3. Dokumentasi gambar, sebagai data tambahan untuk mendukung data yang telah didapat.

\section{Teknik pengolahan data}

Teknik pengolahan data menggunakan teknik analisis data deskriptif kualitatif. Metode penelitian kualitatif adalah metode untuk menyelidiki obyek yang tidak dapat diukur dengan angka-angka ataupun ukuran lain yang bersifat eksak. Penelitian deskriptif kualitatif berusaha menggambarkan suatu gejala sosial. Dengan kata lain penelitian ini bertujuan untuk menggambarkan sifat sesuatu yang tengah berlangsung pada saat studi. Metode kualitatif ini memberikan informasi yang lengkap sehingga bermanfaat bagi perkembangan ilmu pengetahuan serta lebih banyak dapat diterapkan pada berbagai masalah. Metode penyelidikan deskriptif tertuju pada pemecahan masalah yang ada pada masa sekarang. Pengertian penelitian kualitatif dapat diartikan sebagai penelitian yang menghasilkan data deskriptif mengenai kata-kata lisan maupun tertulis, dan tingkah laku yang dapat diamati dari orang-orang yang diteliti.

\section{HASIL DAN PEMBAHASAN \\ Hasil Penelitian}

Hasil penelitian tindakan kelas sebanyak 3 siklus didapatkan data pada tabel dibawah ini

Peningkatan Kreativitas Anak Dalam Menciptakan Bentuk (dalam \%)

\begin{tabular}{|c|c|c|c|c|c|c|c|c|c|c|c|c|c|c|c|c|c|c|}
\hline \multirow{3}{*}{$\begin{array}{c}\mathrm{N} \\
\mathrm{o}\end{array}$} & \multirow{3}{*}{ NamaAnak } & \multicolumn{17}{|c|}{ Hasil Penelitian (\%) } \\
\hline & & \multicolumn{4}{|c|}{ Data Awal } & \multicolumn{5}{|c|}{ Siklus I } & \multicolumn{4}{|c|}{ Siklus II } & \multicolumn{4}{|c|}{ Siklus III } \\
\hline & & 1 & 2 & 3 & 4 & 1 & & & 3 & 4 & 1 & 2 & 3 & 4 & 1 & 2 & 3 & 4 \\
\hline 1 & $\begin{array}{l}\text { Anak dapat menciptakan } 2 \\
\text { macam bentuk geometri } \\
\text { menjadi bentuk yang baru. }\end{array}$ & 13 & 20 & 27 & 4 & 7 & & & 33 & 53 & 0 & 0 & 27 & 73 & 0 & 0 & 7 & 93 \\
\hline 2 & $\begin{array}{l}\text { Anak dapat menciptakan } 3 \\
\text { macam bentuk geometri } \\
\text { menjadi bentuk yang baru. }\end{array}$ & 13 & 27 & 27 & 3. & 7 & & & 33 & 47 & 0 & 7 & 27 & 67 & 0 & 0 & 13 & 87 \\
\hline 3 & $\begin{array}{l}\text { Anak dapat menciptakan } 4 \\
\text { macam bentuk geometri } \\
\text { menjadi bentuk yang baru }\end{array}$ & 20 & 33 & 20 & 27 & 7 & & & 27 & 47 & 0 & 7 & 33 & 60 & 0 & 0 & 13 & 87 \\
\hline 4 & $\begin{array}{l}\text { Anak dapat menciptakan } 5 \\
\text { macam bentuk geometri } \\
\text { meniadi bentuk yang baru. }\end{array}$ & 13 & 22 & 27 & 2 & 1 & & & 34 & 40 & 0 & 7 & 33 & 60 & 0 & 0 & 23 & 87 \\
\hline
\end{tabular}

Aulad : Journal on Early Childhood, 2019, 2(1), $1-8$ 
Dari tabel di atas dapat dipaparkan bahwa hasil unjuk kerja tentang anak dapat menciptakan 2 macam bentuk geometri menjadi bentuk yang baru data awal kategori belum berkembang mencapai 13\%, Siklus I 0\%, Siklus II 0\%, Siklus III $0 \%$. Kategori mulai berkembang data awal mencapai $20 \%$, Siklus I $7 \%$, Siklus II 0\%, Siklus III 0\%. Kategori berkembang sesuai harapan data awal mencapai 27\%, Siklus I $33,3 \%$, Siklus II 27\%, Siklus III 7\%. Kategori berkembang sangat baik data awal 40\%, Siklus I 53\%, Siklus II 73\%, Siklus III 93\%. Untuk 3 macam bentuk geometri menjadi bentuk yang baru Kategori belum berkembang data awal mencapai $13 \%$, masih Siklus I 7\%, Siklus II 0\%, Siklus III 0\%. Kategori berkembang data awal mencapai 27\%, Siklus I 13\%, Siklus II 7\%, Siklus III 0\%. Kategori berkembang sesuai harapan data awal mencapai $27 \%$, Siklus I 33\%, Siklus II 27\%, Siklus III $13 \%$. Kategori berkembang sangat baik data awal mencapai $33 \%$, Siklus I $47 \%$, Siklus II $67 \%$, Siklus III $87 \%$. Sedangkan 4 macam bentuk geometri menjadi bentuk yang baru. Kategori belum berkembang data awal mencapai 20\%, masih Siklus I $7 \%$, Siklus II 0\%, Siklus III 0\%. Kategori mulai berkembang data awal mencapai $33 \%$, Siklus I 20\%, Siklus II 7\%, Siklus III 0\%. Kategori berkembang sesuai harapan data awal mencapai 27\%, Siklus I 34\%, Siklus II 33\%, Siklus III $23 \%$. Kategori berkembang sangat baik data awal mencapai 27\%, Siklus I 40\%, Siklus II $60 \%$, Siklus III 87\%. Serta untuk 5 macam bentuk geometri menjadi bentuk yang baru, Kategori belum berkembang data awal mencapai 13\%, masih Siklus I 13\%, Siklus II $0 \%$, Siklus III $0 \%$. Kategori mulai berkembang data awal mencapai $22 \%$, Siklus I 13\%, Siklus II 7\%, Siklus III 0\%. Kategori berkembang sesuai harapan data awal mencapai $27 \%$, Siklus I $34 \%$, Siklus II 33\%, Siklus III 23\%. Kategori berkembang sangat baik data awal mencapai $27 \%$, Siklus I $40 \%$, Siklus II $60 \%$, Siklus III $87 \%$.

\section{Grafik peningkatan kreativitas anak dalam menciptakan 2 macam bentuk geometri}

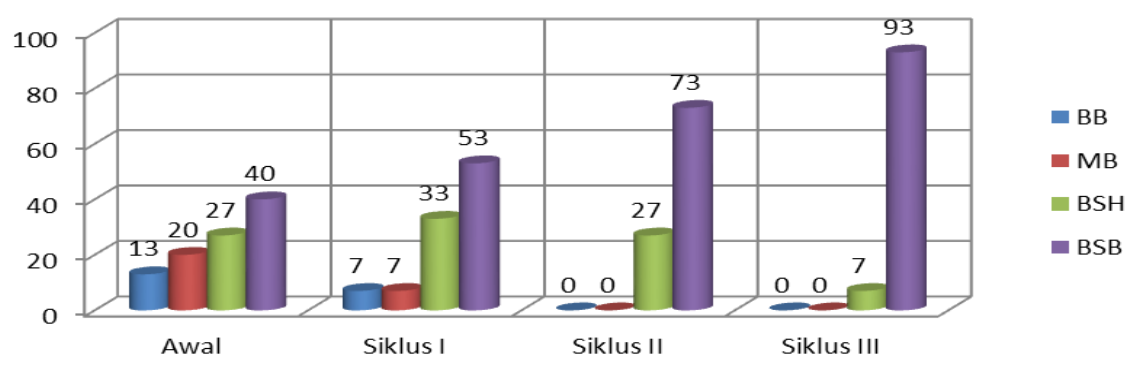

Dari grafik di atas dapat diketahui peningkatan kreativitas anak sebagai berikut :Kategori belum berkembang pada data awal mencapai $13 \%$, siklus I $7 \%$, siklus II $0 \%$, dan siklus III $0 \%$. Hal ini menunjukkan bahwa kategori belum berkembang mengalami penurunan $13 \%$. Kategori mulai berkembang data awal 20\%, siklus I $7 \%$, siklus II $0 \%$, dan siklus III 0\%. Hal ini menunjukkan bahwa kategori mulai berkembang mengalami penurunan $20 \%$. Kategori berkembang sesuai harapan data awal mencapai 27\%, siklus I 33\%, Siklus II 27\%, dan siklus III 7\%. Hal ini menunjukkan bahwa kategori berkembang sesuai harapan mengalami penurunan 20\%. Kategori berkembang sangat baik data awal mencapai $40 \%$, siklus I $53 \%$, siklus II $73 \%$, dan siklus III 93\%. Hal ini menunjukkan bahwa kategori berkembang sangat baik mengalami kenaikkan 53\%. Dari data-data diatas menunjukan bahwa terdapat peningkatan kreativitas anak dalam menciptakan bentuk setelah diterapkannya penggunaan bermacam-macam media geometri. 
Berdasarkan penjelasan diatas bahwa terdapat peningkatan kreativitas anak dalam menciptakan bentuk dengan menggunakan media geometri dinyatakan dapat diterima.

Grafik peningkatan kreativitas anak dalam menciptakan 3 macam bentuk geometri

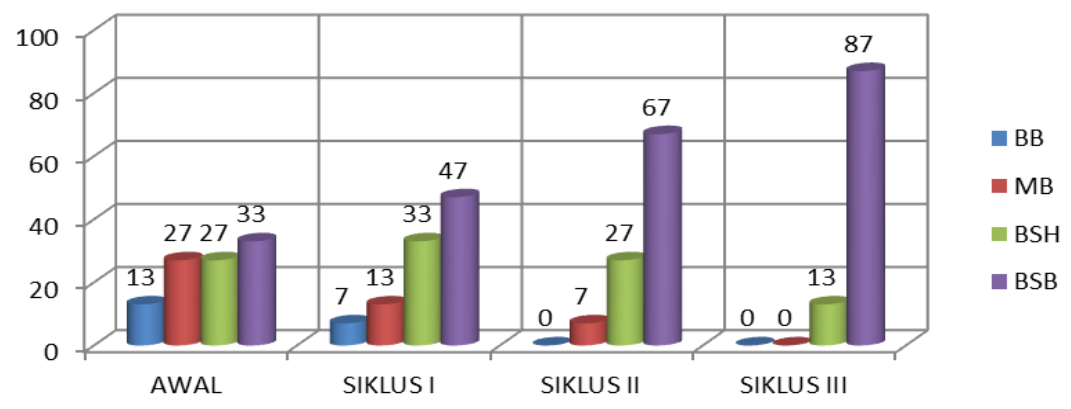

Dari grafik diatas terdapat peningkatan untuk 3 macam bentuk geometri menjadi bentuk baru yaitu : Kategori belum berkembang pada data awal mencapai $13 \%$, siklus I $7 \%$, siklus II $0 \%$, dan siklus III $0 \%$. Hal ini menunjukkan bahwa kategori belum berkembang mengalami penurunan 13\%. Kategori mulai berkembang data awal 27\%, siklus I 13\%, siklus II 7\%, dan siklus III $0 \%$. Hal ini menunjukkan bahwa kategori mulai berkembang mengalami penurunan $27 \%$. Kategori berkembang sesuai harapan data awal mencapai 27\%, siklus I 33\%, Siklus II 27\%, dan siklus III 13\%. Hal ini menunjukkan bahwa kategori berkembang sesuai harapan mengalami penurunan $14 \%$. Kategori berkembang sangat baik data awal mencapai 33\%, siklus I 47\%, siklus II 67\%, dan siklus III 87\%. Hal ini menunjukkan bahwa kategori berkembang sangat baik mengalami kenaikkan 54\%. Dari data-data diatas menunjukan bahwa terdapat peningkatan kreativitas anak dalam menciptakan bentuk setelah diterapkannya penggunaan bermacam-macam media geometri.

Berdasarkan penjelasan diatas bahwa terdapat peningkatan kreativitas anak dalam menciptakan bentuk dengan menggunakan media geometri dinyatakan dapat diterima.

Grafik peningkatan kreativitas anak dalam menciptakan 4 macam bentuk geometri

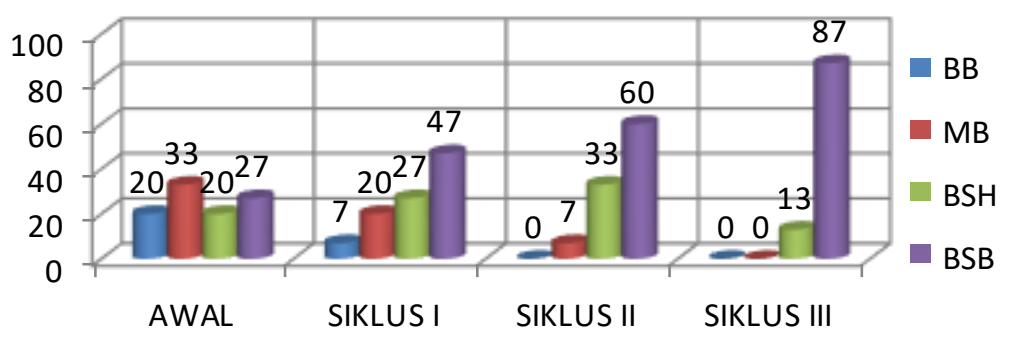

Dari grafik diatas terdapat peningkatan untuk 4 macam bentuk geometri menjadi bentuk baru yaitu :

Kategori belum berkembang pada data awal mencapai 20\%, siklus I $7 \%$, siklus II $0 \%$, dan siklus III $0 \%$. Hal ini menunjukkan bahwa kategori belum berkembang mengalami penurunan $20 \%$. Kategori mulai berkembang data awal $33 \%$, siklus I 20\%, siklus II 7\%, dan siklus III 0\%. Hal ini menunjukkan bahwa kategori mulai berkembang mengalami penurunan 33\%. Kategori berkembang sesuai harapan data awal mencapai 27\%, siklus I 33\%, Siklus II 27\%, dan siklus III 13\%. Hal ini

Aulad : Journal on Early Childhood, 2019, 2(1), $1-8$ 
menunjukkan bahwa kategori berkembang sesuai harapan mengalami penurunan $14 \%$. Kategori berkembang sangat baik data awal mencapai $20 \%$, siklus I $27 \%$, siklus II $33 \%$, dan siklus III $13 \%$. Hal ini menunjukkan bahwa kategori berkembang sangat baik mengalami kenaikkan 7\%. Dari data-data diatas menunjukan bahwa terdapat peningkatan kreativitas anak dalam menciptakan bentuk setelah diterapkannya penggunaan bermacam-macam media geometri.

Berdasarkan penjelasan diatas bahwa terdapat peningkatan kreativitas anak dalam menciptakan bentuk dengan menggunakan media geometri dinyatakan dapat diterima.

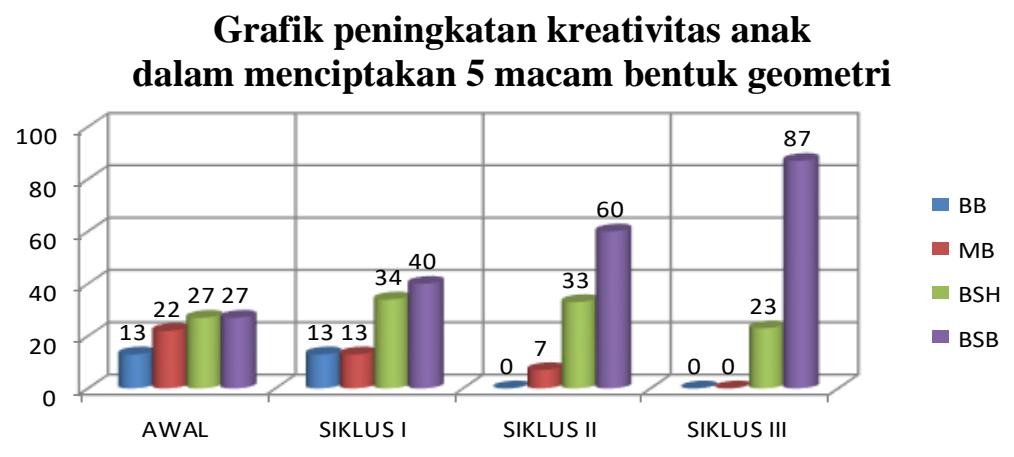

Dari grafik diatas terdapat peningkatan untuk 5 macam bentuk geometri menjadi bentuk baru yaitu : Kategori belum berkembang pada data awal mencapai $13 \%$, siklus I 13\%, siklus II 0\%, dan siklus III 0\%. Hal ini menunjukkan bahwa kategori belum berkembang mengalami penurunan 13\%. Kategori mulai berkembang data awal 22\%, siklus I 13\%, siklus II 7\%, dan siklus III $0 \%$. Hal ini menunjukkan bahwa kategori mulai berkembang mengalami penurunan $22 \%$. Kategori berkembang sesuai harapan data awal mencapai 27\%, siklus I 34\%, Siklus II 33\%, dan siklus III $23 \%$. Hal ini menunjukkan bahwa kategori berkembang sesuai harapan mengalami penurunan $4 \%$. Kategori berkembang sangat baik data awal mencapai $27 \%$, siklus I $40 \%$, siklus II $60 \%$, dan siklus III $87 \%$. Hal ini menunjukkan bahwa kategori berkembang sangat baik mengalami kenaikkan $60 \%$. Dari data-data diatas menunjukan bahwa terdapat peningkatan kreativitas anak dalam menciptakan bentuk setelah diterapkannya penggunaan bermacam-macam media geometri.

Berdasarkan penjelasan diatas bahwa terdapat peningkatan kreativitas anak dalam menciptakan bentuk dengan menggunakan media geometri dinyatakan dapat diterima. Hasil penelitian menunjukan bahwa dalam kegiatan penggunaan media geometri, kreativitas anak dalam menciptakan bentuk mengalami peningkatan dalam keterperincian (elaboration) yaitu anak mampu menyatakan pengarahan ide/gagasan imajinasi dalam bentuk hasil karya sebuah gambar secara terperinci dan detail, teori keterperincian ini berhubungan dengan persentasi peningkatan kreativitas anak dalam menciptakan bentuk.

Hasil penelitian menunjukan bahwa dalam kegiatan media geometri kreativitas anak dalam menciptakan bentuk mengalami peningkatan dalam keterperincian (elaboration). Hal ini juga didukung oleh persentasi peningkatan kreativitas anak dalam menciptakan bentuk yang dikatagorikan kreatif dengan menggunaan siklus, peningkatan tiap siklus diantaranya semua anak dapat menyelesaikan pekerjaan sendiri sesuai imajinasinya menghasilkan banyak gagasan, yang dituangkan kedalam bentuk hasil karya berupa gambar dari susunan ragam bentuk geometri yang masing-masing berbeda dan unik serta semua anak memiliki rasa bangga dan percaya diri terhadap hasil karyanya sendiri, tidak segan atau malu memperlihatkannya juga menceritakan didepan teman atau orang lain. 


\section{SIMPULAN}

Hasil kreativitas anak dengan menggunakan media geometri untuk menciptakan bentuk baru semakin meningkat setelah dilakukan penelitian tindakan kelas yang dilaksanakan secara observasi dan unjuk kerja dari data awal sebelum dilaksanakan penelitian tindakan kelas diteruskan dengan siklus I,siklus II, siklus III. Setelah penerapan tindakan kelas terjadi perubahan-perubahan kreativitas anak dalam menciptakan bentuk baru semakin baik setiap siklusnya. Peningkatan perilaku anak dalam aspek kreatif berkatagori baik pada data awal sebesar 27\%, siklus I sebesar $47 \%$, siklus II sebesar 67\%, dan siklus III sebesar $87 \%$ dengan grafik meningkat. Peningkatan kreativitas anak dalam menciptakan 2 macam bentuk geometri menjadi bentuk yang baru pada katagori anak berkembang sangat baik dengan grafik meningkat terlihat pada data awal sebesar $40 \%$, siklus I sebesar 53\%, pada siklus II sebesar $73 \%$, dan terus meningkat pada siklus III sebesar 93\%. Anak-anak dapat menyelesaikan pekerjaan sesuai dengan imajinasinya dan menghasilkan gagasan yang dituangkan kedalam hasil karya, dengan percaya diri dan bangga anak menceritakan hasil karyanya di depan guru dan teman-temannya. Hal ini memperlihatkan bahwa penggunaan media geometri dapat meningkatkan kreativitas anak dalam menciptakan bentuk.

\section{DAFTAR PUSTAKA}

Arsyad Azhar. (1997). Media Pembelajaran. Jakarta: PT. Raja Grafindo Persada.

Departemen Pendidikan Nasional. (2003). Undang-Undang Republik Indonesia Nomor 20 Tahun 2003 Tentang Sistem Pendidikan Nasional. Jakarta: Departemen Pendidikan Nasional.

Mulyasa, E. (2000). Cara Membuat Alat Peraga Sederhana Bagi Guru Sekolah Dasar. Bandung: CV. Geger Sunten.

Munandar, U. (1995). Dasar-Dasar Pengembangan Kreativitas Anak Berbakat. Jakarta: Departemen Pendidikan Dan Kebudayaan.

Pamilu. (2007). Kreativitas anak [Kamus Webster Online]. Tersedia: Ghana Shakira blog. [18 Januari 2009].

Peraturan Menteri Pendidikan Nasional RI No. 58 Tahun 2009. (2009). Standart Pendidikan Anak Usia Dini. Jakarta: Departemen Pendidikan Nasional Derektorat Jendral Managemen Pendidikan Dasar \& Menengah-Direktorat Pembina TK dan SD.

Rachmawati, Y. dan Kurniati, E. (2003). Strategi Pengembangan Kreativitas. Bandung: Departemen Pendidikan Nasional.

Safaria. (2005). Panduan Mencetak Anak Super Kreatif. Jakarta: Rineka Cipta.

Sriningsih, N. (2008). Pembelajaran Matematika Terpadu Untuk Anak Usia Dini. Bandung: Pustaka sebelas.

Sudono, A. (1995). Alat Permainan Dan Sumber Belajar. Jakarta: Departemen Pendidikan dan Kebudayaan.

Sugiyono . (2008). Metode Penelitian Kuantitatif Kualitatif dan R\&D. Bandung: Alfabeta.

Wardhani, dkk. (2007). Penelitian Tindakan Kelas. Jakarta: Universitas Terbuka. 